\title{
THE BETTERMENT OF THE CONDITIONS OF WORKING WOMEN
}

\author{
By Edward A. Filene, \\ Boston, Mass.
}

So large is the number of women working for a living, so fast is that number increasing, that an examination of the conditions under which they are employed is well not only from the standpoint of the workers, but also from that of society. Such an examination quickly shows that many women work under conditions that are a serious menace, both to their own welfare and to that of our social institutions, our family life, and our democracy. We find great numbers of women and young girls working for sums that are not living wages, in unsanitary quarters and for too long hours.

Let us briefly look into the conditions of three groups of women workers. Each of these groups differs from the others, but together they seem to me to bring out clearly the evils of the conditions under which women work and their possible remedies. The three groups are: (I) Those working in factories and workshops; (2) store workers, and (3) domestic servants. The worst conditions of the three groups are found in factories, workshops, laundries, and similar industries in cities. In these the wages of the unskilled women workers are very low and the hours, strain of work and environment are often such as should not be tolerated by a decent society.

The conditions are worse in proportion as the trade is unskilled. In trades which require no special training or skill great numbers of women and girls are willing or are forced to work for three to five dollars a week, and are not steadily employed even then. Moreover, so many women and girls are always at hand to take vacant places that there is no pressure from that most effective source, the scarcity of workers, to increase wages and improve conditions.

The fundamental cause of the trouble lies in the fact that great numbers of women and girls are forced to work who have never been trained to work-who do not know how to work-who do not know how to keep themselves well-who lack the qualities necessary (613) 
to enforce their rights-who lack the intelligence and necessary will power to organize for their own and society's rights. My experience leads me to believe that the greater part of so-called unskilled trades can be practically put into the class of skilled trades if sufficient training is provicled; for training will enable the workers to produce more and of a better quality, and even with higher wages, will reduce rather than inrease the cost of production.

The duty of such industrial training lies upon society-upon us. The time has come for us frankly to admit that our educational system is a class system, for, with more than 90 per cent. of our children ending their school education with the grammar school, and with a certainty from the beginning that they must start to earn their living at the end of such a grammar school course, we have nevertheless made almost no direct attempt to prepare them for their life work. The time is here to confess that we have erred frightfully. The time has come, as we look upon the victims of our mistakes in our streets, factories, jails, hospitals, and almshouses, to show our repentance by work that shall never end until our public education is vocational industrial education. Education in a democracy must be vocational.

With the alarming facts of the women workers and child labor before us, it is too late to grant any longer the theoretical claims of classical educationalists that the whole end of education is culture. Or, at least, we should reply, that if they be right, then they must make vocational education cultural and we should enforce our reply with the stunted figures, the starved bodies and souls of the victims of our present educational system. You cannot teach spiritual truths to starving bodies.

Germany has already produced the results I am pleading for in practically less than thirty years. She has established a compulsory system of industrial vocational education, so that every boy learns how to work, either in the day or evening school. What Germany has done we will do. Our needs, our conscience, our common humanity compel us.

As a result of the large supply of trained workers coming from such a reform there will be little or no place for wholly untrained workers, and the demand for untrained immigrants, and therefore the supply of such workers willing to live and work under un-American conditions, will proportionally decrease. 
As a further result, another remedy, thought by many to be the only adequate one, will become more powerful as a corrective for the evils under which women work. I mean that when the untrained workers are no longer suitable to replace the average workers, then it will be far more possible to organize women workers in unions. The ability of women workers to enforce their just demands is minimized as long as they can be replaced by an almost unlimited supply of untrained non-union workers.

There are other reasons why it seems to me that at present it is almost hopeless to expect adequate results from trade organizations of women workers until industrial training has done at least a part of its work. What is it that prevents working women from combining successfully and thus gaining the power to enforce their just demands as the male workers do by the help of their unions? Lest I be accused of being prejudiced, and of judging from the man's point of view, I am going to give you the answers of some wise women-wise because they judge this problem not only with knowledge but also with sympathy.

In a consultation I had recently with a woman whose profession is industrial betterment work, she said :

"Regarding the organization of women in clubs and unions, as to clubs, they have been fairly successful; the women like to get together at the noon hour if there is music provided, and after work hours for social entertainment.

"As to women joining unions, there are three principal reasons, in my experience, why they do not.

"First. Lack of courage. The average factory working woman has not the same courage as the factory-working manl, and the women hesitate to undertake an aggressive policy.

"Second. Marriage. By reason of expectation of marriage, the wage question does not present itself so definitely as likely to be an important question all their lives. They expect to escape by marriage from whatever pressure there is from insufficient wages.

"Third. Factory women, as a whole, are not as intelligent as factory men are. They will not take time to study labor questions, or the technique of their trade; their reading, in my experience, is almost wholly novels and light literature, while in the same plants the men to a far greater degree take from the libraries serious books which will educate them along the lines of their work."

In Western Pennsylvania, where most of this woman's experience has been, she found that a great many of the factory working $(615)$ 
women are daughters of women who worked in the factories before them, and who went into factory life at an early age, and got only the most necessary schooling-as much as the law compelled them to take. But, where there are more high school girls in the factories, as in Eastern Pennsylvania, even there they want their evenings for entertainment and pleasure, and are not willing to devote them to study or serious reading.

Another wise woman, also a professional social worker, said to me :

"The Women's Trade Union League feels that women and children form a helpless class in industrial competition as regards hours, wages, and conditions of work, because they have continued to bargain for their labor individually. We feel that the best thing for them to do is to follow the line of trade unions and to bargain collectively."

This woman concludes from her experience that the reasons why women do not form unions are:

I. They feel that they are not going to stay in trade very long -they look forward to marriage.

2. They have less intelligence than the men and a narrow outlook. Some girls told her they believed in the union, but it did not mean anything to them personally. They were not willing to sacrifice a part of their salary for the dues. She thinks they do not understand what the union represents.

3. They are diffident. You cannot get them out to the meetings-that they "will come if the others come," is the most they will say.

Still another says: "The suffragists will tell you that the ballot will awaken in women that self-respect and sense of responsibility they lack. My own feeling is that many poor women dread unions, as they associate them with strikes and fighting. The policy of the 'closed shop' though doubtless a necessary method to meet the aggressions of the other side, leads to a violence, repugnant to the mind of a woman whose training has been to please, to make things pleasant."

Another woman, whose sympathy is as broad as her knowledge is deep, writes, in part:

"The chief reason why women do not readily combine in trade unions is because the woman wage earner is a rapidly changing creature. The average wage earner among women is a wage (6I6) 
earner lass than five years, so far as continuous service is concerned. The minority of women who continually serve in 'gainful occupations,' as the census calls it, are not numerous enough, nor themselves determined enough, to keep in that class as a life devotion, to give the body of women workers leadership."

Trade unionism among men gets its strength from two basic convictions on the part of men wage earners: The first is that the wage earners' position is a permanent one; that is to say that the old, rapid and frequent changes from the position of wage earner to head of a business or small factory are for the most part gone in this day of large concerns, great capital and highly organized management.

The second conviction that makes the strength of men's trade unions is that of the individual workers that they will work for a long term of years in exactly the same relations, and that, therefore, each one must gain, if at all, in wages, hours, and in general condition by combined effort.

Women lack both these convictions because the majority of women wage earners do not expect to remain permanently in any work outside the home and, therefore, they see no reason why they should combine for mutual benefit. They are not more selfish than men were under the old order, when they did not try to improve, but to escape from, the bad conditions of the average wage earner.

In the case of women, however, there is added a more serious menace to the kinds of labor in which they are especially employed, since the understanding that they will not remain long as individuals in work outside the home, and that they are seeking generally not full but partial support for this limited time, makes employers able to offer and makes women willing to receive (without full consciousness on either side of the magnitude of the social crime thus perpetrated) less than a living wage for full time work.

This constitutes a permanent difference in the relation of men and of women to trades unionism. While welcoming the new movements toward trades unionism among women in so far as they succeed in developing a class spirit strong enough to forbid the present almost universal underbidding among women, and also so far as they draw women of all classes together for a more thorough study of industrial conditions as they affect the sex, I do not anticipate anything like the practical amelioration of bad labor 
conditions for women by means of the trade union movement which men have secured for themselves by the same movement.

But I look to advanced legislation, well administered, more than to trade unionism to better the condition of the wage earning woman, for she is, as a majority class, too young, too ignorant, too short-termed in her industrial relation, and, therefore, in too large a proportion unskilled, to "know her rights and dare maintain them." While making due allowance for the many different causes pointed out by these opinions, yet it seems to be that here again vocational industrial education which includes some simple courses in economics will do mucl to fit women for organization into unions to enforce their rights.

Let us briefly consider the second group, the store workers:

The chief defects of the conditions of women workers in stores are underpay, the strain of work, and, for some, instability of work. The most important of these defects are due to lack of training for their work and an oversupply of workers; and these in turn are largely due to the fact that store work is as yet practically an unskilled occupation.

But in almost all stores the value of the merchandise, or what amounts to the same thing to the employers, the number of valuable customers, is largely enhanced by an increase in the intelligence and skill of the saleswomen. Now whatever pays in retail business will be done if it is practically possible to do it. Competition sees to that. Therefore, within a reasonable time, storekeepers will see to it that the greater skill and intelligence which pay better are supplied.

Many stores have already begun to train their employees in store classes; and in Boston we have had for three years a class in the evening school for salespeople, and the Women's Educational and Industrial Union has had another class this year. As a result of these and similar successful experiments elsewhere, I feel confident that there will be established in time a standard for salesmanship which will take it out of the unskilled trades, and thereby largely diminish, if not abolish, the surplus supply of store workers, and correspondingly increase wages.

The public can help in the attainment of these desired reforms by demanding good conditions for the workers and intelligent, skilled service from salespeople, and by giving patronage to the 
stores that supply these requirements. This the public can afford to do from self-interest, if from no other motive, for skilled and intelligent salespeople mean, all in all, better goods and lower prices and more opportunity of getting the right thing.

Even now there is a great shortage throughout the country of women capable of filling those positions in stores which pay very good wages, which require more than the average skill and intelligence, but which are not out of reach of a thoughtful, determined store worker of no extraordinary ability. Moreover, it is a general truth that even now the percentage of cost of wages to sales is usually less for the higher priced, skilled salespeople than for the cheaper, less skilled ones. It appears to me, therefore, that this kind of vocational education, public or private, is bound to come, and in coming will fix a standard of skill for store workers high enough to advance wages, especially by making it impossible for the great numbers of unskilled girls and women to compete for store work at wages that are not living wages.

At this point the question naturally arises, What will become of the unskilled workers? The supply of unskilled workers from immigration will, in a large measure, be diminished or stopped when there is little demand for them, because a large number of immigrants are induced to come by the feeling of certainty that there is work to be had in this country, even though the immigrant is unskilled, at wages which are living wages to them in the countries from which they come. Yes, living wages, according to the standards such immigrants have been forced to submit to and judged by the cost of living in their own country, but not living wages by American standards. The supply of unskilled American workers will be correspondingly decreased by the lack of demand for them, and parents will be forced to keep their children in school long enough to be taught how to work, and, in most cases, to acquire some vocation.

But it may be argued that there is danger of an oversupply of trained workers, making conditions worse than before. I think that this is not to be feared, for the chief evils of the conditions under which the groups of women we are discussing work are the same that men have had to contend with and which they have conquered in proportion as they have become more intelligent and better trained to work. 
The servant girl problem differs from the problems affecting the other classes considered. Here we find a group of workers that is comparatively well paid and whose conditions of work are generally considered to be far better than those of the factory workers. Yet our American homes and family life are threatened by the servant girl problem. Good servants are not to be had in sufficient numbers. And it will continue to be impossible to obtain them in such numbers until conditions are made so much better that women who have any ambition or any choice at all will no longer refuse to enter this occupation, and that the more intelligent servants themselves will no longer go into some other kind of employment as soon as opportunity offers.

Investigation shows that the causes of this state of affairs are not low wages and bad material conditions-are not the causes that are fundamental to the evils of the conditions of women in factories and stores. What then are the causes? We can best ascertain them by reviewing an actual incident.

A woman came into our store one day with a letter of introduction that asked for her the privilege of interviewing our employees. She stated that she was employed to help the solution of the servant girl problem, and incidentally to help factory and store girls by placing them in good houses as servants. As she was evidently inexperienced, I ventured to tell her she had a very difficult task before her and offered to help her with the first few she interviewed, granting her the privilege of interviewing alone thereafter as many more as she cared to see.

Together we talked to three saleswomen who were not selected, but who were taken by chance as business brought them to my office. The first girl was about sixteen. My visitor offered her a short training free to begin with and then four dollars a week and board and lodging in a family where good treatment could be assured. The offer was promptly declined, with the explanation that she would not be a servant at any price; for if she were, her friends and schoolmates would look down upon her.

"But," I said, "you can get four dollars a week and board and lodging, while as an apprentice here you get only four dollars a week without board and lodging." "Yes," said she, "but I don't pay for board and lodging at any rate. I live at home and all apprentices get six dollars at the end of the first year, and then I'll 
be a salesgirl and earn at least eight or ten dollars-and all the time I'll have my evenings and Sundays for myself."

The next girl interviewed also refused to consider the offer, saying that nothing would induce her to become a servant; a salesgirl's work was more interesting-she saw more of life-saw more well-dressed ladies, and could copy their dress and the way they talked-had much more free time.

The next girl emphasized the loss of social position in becoming a servant. None of the men with whom she associated, she said, would marry a servant. Last summer her vacation had been spent at a hotel, where she had a good time, and nobody at that hotel had thought less of her for being a salesgirl, but no one there would have talked with her had she been a servant.

Thereupon one of our young women who is a buyer at a salary running into the thousands came into the office. My visitor was going to interview her also, but I am glad to say that I was strong enough to overcome the malicious delight offered by the prospect of what would happen to the one who was herself unwilling to become a domestic servant if she asked this girl (the buyer) to become one.

In short, it is almost needless to say that my visitor did not get a single recruit, and that I have never known of a salesgirl becoming a servant. I think this incident confirms the general conclusions of investigators of the servant problem, that the comparatively good wages and possibilities of steady work do not compensate for the loss of social position, the loss of independence and the lack of leisure time.

My own investigations force me to the conclusion that in this domestic servant problem lasting reform must begin with the employers and not with the employees. And this is doubly necessary, for the evils that threaten the home from this source at the same time threaten our democracy. For the causes of these evils are lack of sympathy, lack of understanding on the part of the average mistress, who, as a rule, looks at the servant from a class point of view.

It is of course an axiom that a democracy cannot live if class distinctions grow and multiply constantly. But that is what in the natural order of things has come about in our country from things that were done with good motives. For as we became richer we 
moved our families from the less desirable, more crowded districts where they had been living, to sections where there was more room, more sunshine and more air-all things worthy to be sought for. But we left behind our neighbors without more air, without more sunshine, with a narrower life in every way.

And for them democracy took up the fight. For the God that made the universe and universal law has not made His standard of right conform to that of man. In His omniscience, He has made the law that is and will be steadfast for all time, and he who tries to break it suffers even if he attempts to break it in the belief that he is right, and with the best motives. That is the supreme thing in this world-the steadfastness of the law of the universe-God's law; and that it does not change even for the right-man's idea of right.

And so when, instead of improving conditions we tried to escape them, when we moved away from our less fortunate neighbors, and sent our children to our own special schools, and went to our own special clubs and our own special churches, and lived largely with our own class, and lost contact with and comprehension of the masses, we broke God's law of brotherhood-democracy -and sowed the seeds from which grew suspicion, prejudice and class differences, which are at the bottom of our political, religious, educational and industrial troubles in this country. We sent our children to private schools, or to the public schools of these better districts, which at the best offered no opportunity for meeting and understanding the girls who were likely to become servants, or at any rate who had the point of view of those likely to become servants. Thus we lost knowledge of the masses we had left behind with less sunlight and less good air and fewer of all the good things in life we enjoy. And losing knowledge, we lost also sympathy, and lost the power of handling wisely such problems as the servant girl problem. For democratic wisdom is knowledge, plus sympathy, plus love.

When this estrangement has taken place we introduce into our homes these women whom we do not understand, whom we do not sympathize with, and depend on them for orderly, peaceful homes. The situation is impossible, and I, for one, am thankful that it is impossible.

If it were possible to cure the evils of the servant problem permanently by anything less than genuine sympathy and under(622) 
standing, I should despair of the future of our democracy. For class distinction would continue to grow and we should finally have a plutocracy instead of a democracy. Yes, the basis of the servant problem is a class point of view-a lack of sympathy and understanding-even as it is the basis of municipal corruption when it enables demagogues and grafters to get control of voters by appealing to social, religious and class prejudice.

Thank God for the present servant girl problem-is what it seems to me every true lover of democracy must say as soon as he analyzes causes and sees their meanings and tendencies impersonally. The remedies to be applied to the solution of this problem are simple, as simple as all really fundamental remedies must be. Let us love our neighbors. Let us have genuine good-will for our really nearest neighbor-our employees-the ones who work for us and with us. Let us be really democratic. Let us acknowledge the dignity of labor. Let us judge labor by its social value. Thereupon household work will no longer be a stigma, shutting out the worker from all higher social companionship and attainment. Thereupon the hours of work will be adjusted so as to compare favorably with factory and store work, adjusted so as to leave leisure for development and pleasure. We should all rejoice that the only permanent remedy for the ills of democracy is more democracv.

In conclusion, it seems to me that grave as are the evils we are studying, still, unless $I$ have erred entirely as to the needed remedies-the future is full of hope. For they are remedies possible to be achieved by work and devotion, if what is needed is, first, vocational (industrial) public education: second, the effective organization of working women; third, more sympathy and understanding-more real democracy-expressing itself in work for the common good, more neighborliness, and wise, progressive, remedial legislation. 